\title{
Učeničko kumulativno povezivanje faza životnih ciklusa egzemplarnih organizama
}

\author{
Dorotea Vrbanović1, Ines Radanović ${ }^{2}$, Valerija Begić ${ }^{3}$ \\ ${ }^{1}$ V. gimnazija, Klaićeva 1, 10000 Zagreb \\ doroteavrbanovic@gmail.com \\ ${ }^{2}$ Biološki odsjek Prirodoslovno matematičkog fakulteta Sveučilišta u Zagrebu, Rooseveltov trg 6, 10000 Zagreb \\ ${ }^{3}$ Osnovna škola Sesvetski Kraljevec, Školska 10, 10361 Sesvetski Kraljevec
}

\begin{abstract}
SAŽETAK
Cilj ovog istraživanja bio je odrediti usvojenost i konceptualno razumijevanje koncepta Životni ciklusi kod učenika osnovne škole i gimnazije. U svrhu ostvarenja cilja učenici su rješavali slikovne zadatke primjene znanja i konceptualnog razumijevanja u on line sustavu e-učenja MoD. Analiza učeničkih odgovora uključivala je kodiranje odgovora i tumačenje biološkog značenja odgovora. Izdvojeni su i objašnjeni problemi i miskoncepcije vezani uz koncept Životni ciklusi te je analizirana uspješnost učinka kumulativnog provjeravanja. Prosječna riješenost provjere za $10 \%$ odudara od srednje riješenosti provjera iz biologije na nacionalnoj razini. Pogrešan odabir slika za pojedine faze unutar životnog ciklusa upućuje na nedovoljnu vizualizaciju bioloških sadržaja od strane učenika, jer učitelji nisu u poučavanju koristili univerzalne obrasce, odnosno na njih upućivali. Slabije snalaženje učenika u univerzalnom obrascu posljedica je izostanka ili nedovoljne upotrebe grafičkih organizatora znanja tijekom učenja te nedovoljnog naglašavanja principa i poveznica pri poučavanju životnih ciklusa različitih organizama. $\mathrm{Na}$ rješavanje zadataka vezanih uz životni ciklus u kumulativnom slijedu učenja utječe složenost zadataka, kao i bolje poznavanje organizama koji se provjeravaju u povezanosti sa iskustvom učenja prema razini obrazovanja. Utvrđene miskoncepcije i problemi ukazuju na potrebu uvođenja nastavnih tehnika kao što je kumulativno učenje, uz izraženiju potrebu za vizualnom $\mathrm{i}$ iskustvenom potporom te uspostavljenjem uzročno-posljedičnih veza pri učenju.
\end{abstract}

Ključne riječi: osnovna škola i gimnazija; koncept Životni ciklusi; konceptualno razumijevanje; kumulativno učenje i provjeravanje

\section{UVOD}

Osnovna ideja kumulativnog učenja je da učenik rješava niz povezanih zadataka u određenom redoslijedu, pri čemu se ubrzava rješavanje i razumijevanje sljedećeg u nizu zadatka koristeći se naučenim informacijama (Gagné, 1985). Drugim riječima, učeniku se daje prednost pri rješavanju novog zadatka, jer mu je omogućeno korištenje informacija koje je već usvojio rješavanjem prethodnih zadataka. Učenik napreduje u svom razvoju, ne zato što je usvojio jedan ili više elemenata, već zato što in je naučio $u$ određenom redoslijedu koji se nadovezuju jedan na drugi misaonim procesima: diferencijacijom, prisjećanjem i prenošenjem znanja (Furby, 1972). Naglasak se stavlja na reorganizaciju znanja, a ne samo na njegovo usvajanje. Učenik mora naučiti niz vještina prije nego li bude sposoban izvesti zadanu radnju. On napreduje prikupljajući niz vještina u hijerarhijskom slijedu. Treba uzeti u obzir da to napredovanje može imati nekoliko različitih puteva jer je moguće steći potrebne vještine na različite načine (Gagné, 1985). Furby (1972) objašnjava da se svaki zadatak može raščlaniti na podređene vještine potrebne za njegovo uspješno izvođenje, prema tome svaki zadatak se može kumulativno naučiti. Isti autor naglašava da takav pristup olakšava učenje u višim fazama obrazovanja kada je hijerarhija vještina usvojenih za uspješno rješavanje zadatka gotovo završena, jer je potreban samo mali korak, „magični ključ“ za izvršenje zadatka. Međutim, za izvršenje nekih zadataka „magični ključ" se nikada ne otkrije zbog krivih pretpostavka što bi on mogao biti te krive pretpostavke učitelja da je hijerarhija vještina za rješavanje zadatka kod učenika usvojena (Furby , 
1972). Kumulativno organiziranje znanja sličnosti i povezanosti koncepata opisuju Bharadwaj i Kanddwal (2008), jedan od načina kojim to možemo prikazati su klasteri u obliku drva, gdje korijen predstavlja najosnovniji koncept, svaka manja grana je detaljnija i sve užeg koncepta od veće roditeljske grane, a kako se pomičemo prema sve manjim granama, koncept je sve specifičniji. Isti autori ističu da takav način koncipiranja znanja sakuplja fragmente znanja i prezentira ih kao jednu povezanu cjelinu te kao takav reducira veličinu specifične baze znanja. Uočavanjem principa koji sažima klaster, učenicima se olakšava pristup određenim dijelovima znanja i smještanju tog znanja u koncepte kao i njihovo povezivanje. Huang i Frey (2008) opisuju sličan način organiziranja znanja te navode da se problem grupiranja povezanih podataka može smanjiti upotrebom kumulativnih mreža kroz više različitih primjera.

Učenici dolaze u školu s različitim idejama i objašnjenjima svijeta oko njih. Te ideje se razlikuju od učenika do učenika i osim o načinu učenja i poučavanja ovise i o životnim okolnostima. Različita iskustva, razgovori s drugim vršnjacima, starijim osobama i mediji mogu znatno utjecati na njihov pogled na svijet. Takva razmišljanja često se razlikuju od mišljenja znanstvenika, a opisana su kao miskoncepcije. Općenito, miskoncepcije odgovaraju konceptima koji imaju individualne interpretacije i značenja u artikulacijama učenika koja nisu znanstveno točna (Bahar, 2003). Većina učenika ne zna da su njihove ideje krive, a i kada im se kaže da su u krivu teško odustaju od svojih ideja osobito ako tu miskoncepciju imaju duže vrijeme. Često ne vide razlog za promjenu svojih uvjerenja jer ih mogu objasniti, odnosno opravdati iskustvima iz svakodnevnog života (Tekkaya, 2002).

Učitelji biologije trebaju odlučiti što žele da njihovi učenici znaju na kraju svake nastavne teme, a ne bi se trebali opterećivati obradom svakog detalja unutar određene teme (AAAS, 2010). U tu svrhu pri pripremi nastave osim nastavnog plana i programa ili kurikuluma treba koristiti konceptualni okvir (Radanović i sur. 2015) kao smjernicu za pripremu nastave. Koncept Životni ciklusi pripada makrokonceptu Razmnožavanje i razvoj organizma, a zastupljen je u nastavnim sadržajima prirode i biologije za učenike od petog razreda osnovne škole do četvrtog razreda srednje škole. Ključni koncept Životni ciklusi uključuje dva koncepta, Životni ciklus stanice i Životni ciklus organizma. Oni obuhvaćaju sljedeće ishode učenja: analizirati životni ciklus stanice, objasniti osnovno načelo izmjene generacija i redukcije gametofita u autotrofnih organizama, usporediti životne cikluse životinjskih organizama te usporediti faze u životu čovjeka s obzirom na psihofizičke značajke (NCVVO, 2017). Na kraju osnovne i srednje škole učenik je upoznat sa životnim ciklusima svih predstavnika živog svijeta. Uz pomoć predloška učenik bi trebao moći opisati sve životne cikluse kao i moguće specifičnosti svakog od njih (Freiman i sur., 2001).

Cilj ovog istraživanja bio je analizirati učeničke odgovore na zadatke popunjavanja shema životnog ciklusa egzemplarnih organizama on-line provjere pripremljene prema kumulativnim principima učenja, kako bi se utvrdila usvojenost i miskoncepcije koncepta Životni ciklus kod učenika u osnovnoj školi i gimnaziji.

\section{METODE}

Istraživanje je provedeno analizom odgovora po oko 100 učenika osnovne škole (OŠ) i gimnazije (G) na provjeru u on line sustavu e-učenja MoD (SRCE, 2018). Primijenjena su pitanja tipa "Prenesi i postavi na sliku" u kojima učenik treba ponuđenu sliku prenijeti na određeno mjesto bazičnog crteža ili sheme. Učenici su trebali popuniti osnovnu univerzalnu shemu životnog ciklusa (slika 1) crtežima koji prikazuju faze životnih ciklusa egzemplarnih organizama. 


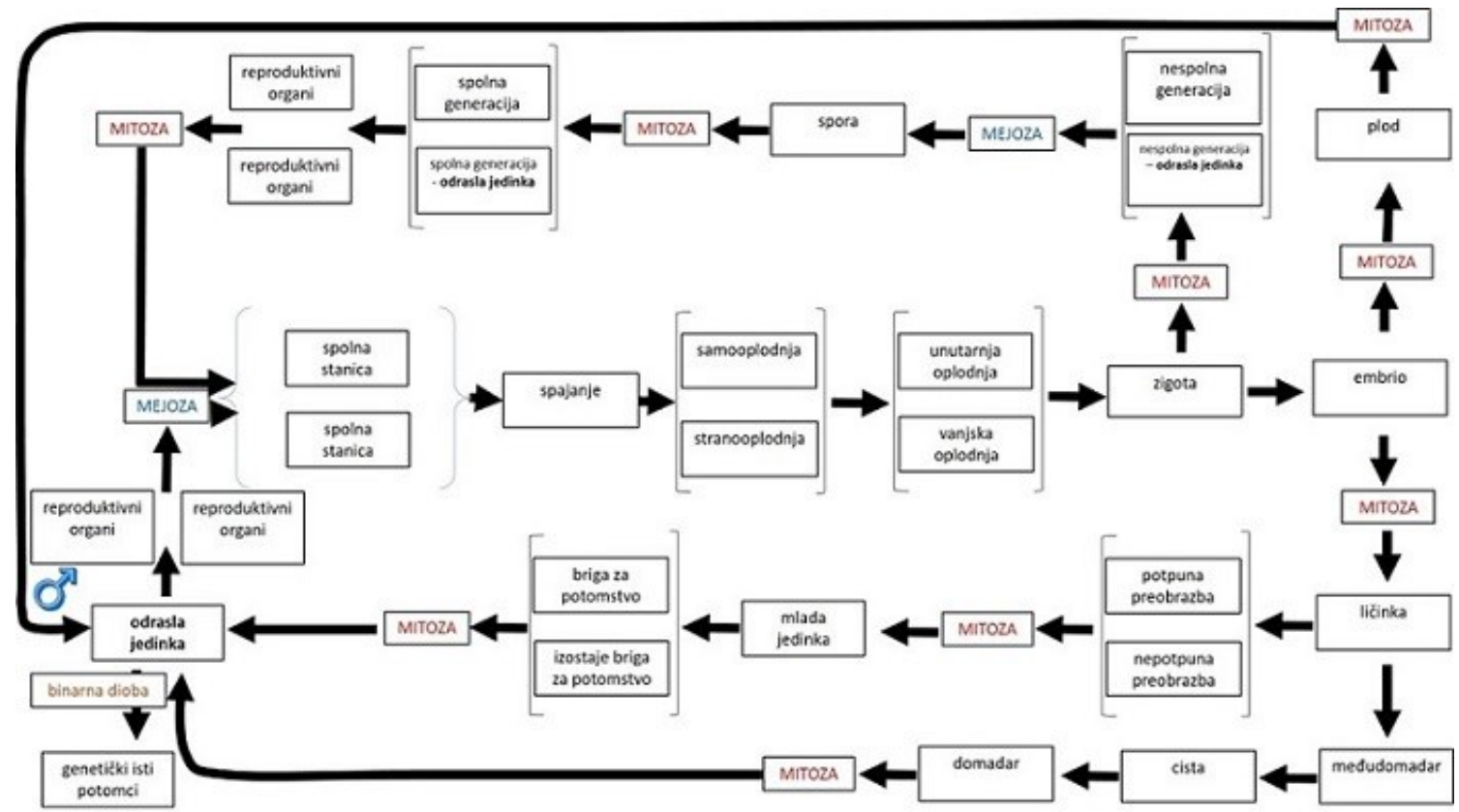

Slika 1. Univerzalna shema životnog ciklusa

Od učenika se tražilo da uz životne cikluse različitih organizama pokažu razumijevanje životnih ciklusa, uoče razlike i sličnosti pojedinih faza i procesa, kao i specifičnosti u pojedinim slučajevima te njihovu povezanost sa životnim uvjetima staništa na kojem živi određeni organizam. Organizmi su određeni u skladu s prethodim znanjem učenika. Kako bi se upoznali s načinom rješavanja učenicima su dane video upute i probni zadatak povezivanja faza u životnom ciklusu čovjeka. Životni ciklus čovjeka odabran je kao probni zadatak, jer se pretpostavlja da su učenici s njime najbolje upoznati i da mogu konceptualno povezati faze u životnom ciklusu. Slijedili su životni ciklusi kokoši, jabuke, euglene, leptira, žabe, ježinca, mahovine, metilja, skakavca i ribe za učenike osnovne škole i gimnazije te životni ciklus gljive za učenike gimnazije.

Analizirala se sposobnost učenika da konceptualno razmišljaju o životnim ciklusima i da pojedinačne informacije o nekom životnom ciklusu, koje su trebali usvojiti tijekom učenja biologije, mogu predstaviti i koristiti u kumulativnom obliku, te kako se ta sposobnost mijenja kroz stupnjeve obrazovanja i tijekom primjene kumulativnog pristupa pri rješavanju provjere. Učenički odgovori analizirali su se metrijski, nakon prethodno provedenog kodiranja uz dodjeljivanje apsolutnih vrijednosti koje omogućavaju statističku analizu prikupljenih podataka uz njihovo kvantificiranje. Svaki odgovor dodatno je procijenjen prema kriterijima točnosti, razini razumijevanja te prisutnosti problema i miskoncepcija prema prilagođenoj metodologiji Radanović i sur. (2017). Zbog potrebe interpretacije odgovora u kontekstu biološkog konceptualnog razumijevanja koristila se metodologija specifičnog kodiranja biološkog značenja točnih, odnosno netočnih učeničkih odgovora prema Radanović i sur. (2016). Za usporedbu riješenosti zadataka prema kognitivnim razinama koristila se metodologija svrstavanja učenika u 10 klasa uspješnosti prema ukupnom postignutom uspjehu, na osnovu čega možemo govoriti o postojanju miskoncepcije kada se ona javlja u odgovorima kod većine klasa riješenosti (Lukša i sur., 2016). Pogrešni odgovori koji nisu karakteristični za sve učenike sugeriraju moguće miskoncepcije kod dijela učenika, jer ako se one ne javljaju kod velikog broja klasa riješenosti možemo samo na njih ukazati, ali ne ih i potvrditi. 
Spearmanovim koeficijentom korelacije $(\rho)$ utvrđena je povezanost slikovnih zadataka u kumulativnom slijedu provjere koji je sadržavao element učenja usložavanjem zadataka i njegove povezanosti na prethodno riješen zadatak. Za interpretaciju rezultata korištena je skala prema Hopkinsu (2000). Multidimenzionalnim (ALSCAL) skaliranjem kvadratnih udaljenosti te dendogramom na osnovu analize prosječne povezanosti između zadataka kumulativnog rješavanja slikovnih zadataka u on line okruženju utvrđene su poveznice i razlozi koji su mogli utjecati na riješenost zadataka. Analize su provedene Microsoft Excel proračunskim tablicama, a statistički proračuni izrađeni su pomoću programskog paketa SPSS 22 (IBM, 2013).

\section{REZULTATI}

U rješavanju provjere u on line sustavu e-učenja MoD sudjelovalo je 193 učenika. Od toga je 97 učenika osnovne škole i 96 učenika gimnazijskog programa srednje škole. Od 97 učenika osnovne škole njih 95 \% pohađa sedmi razred, 3 \% šesti razred i $2 \%$ osmi razred osnovne škole, a svi učenici gimnazije pohađali su drugi razred. Prosječna riješenost provjere za osnovnu školu je $31,86 \%$, dok za gimnaziju ona iznosi $27,48 \%$ (slika 2 ).

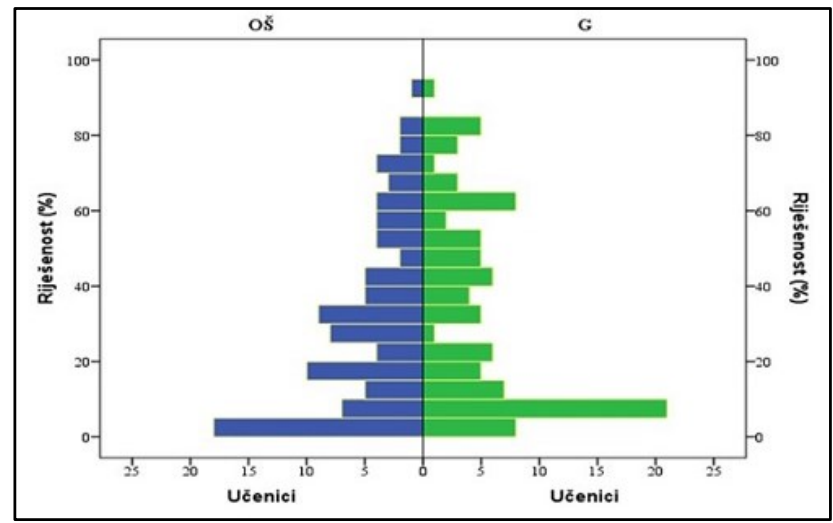

Slika 2. Srednja riješenost provjere za učenike osnovne škole i gimnazije

Kako bi uspješno povezali faze životnog ciklusa egzemplarnih organizama, od učenika osnovne škole se očekuje razumijevanje i primjena znanja koje su stekli tijekom obrade nastavnih cjelina u petom i sedmom razredu osnovne škole, posebno u sedmom razredu osnovne škole kada se upoznaju sa načinima razmnožavanja i životnim ciklusima predstavnika svake od skupine biljaka i životinja. Od učenika gimnazijskog programa srednje škole očekuje se razumijevanje i primjena znanja stečenih tijekom osnovne i srednje škole. Osobito u drugom razredu gimnazije kada detaljnije obrađuju načine razmnožavanja i životne cikluse predstavnika svake od skupine biljaka, gljiva i životinja. Prilikom rješavanja svakog sljedećeg zadatka u slijedu, od učenika se očekuje primjena znanja i pravilnosti koje su stekli tijekom rješavanja prethodnog zadatka u skladu s postavkama kumulativnog učenja.

Prema ukupnom uspjehu učenika u rješavanju provjere znanja, definirano je deset klasa riješenosti. Određen je ukupan broj učenika koji su sudjelovali u rješavanju provjere prema klasama riješenosti (slika 3) te srednja vrijednost riješenosti za svaku klasu (slika 4). Veliki broj učenika svrstanih u prvu klasu riješenosti posljedica je velikog broja neodgovorenih pitanja. 


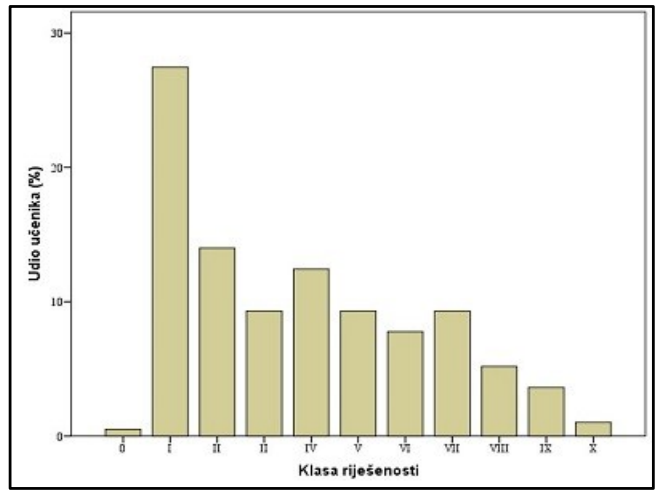

Slika 3. Udio učenika prema klasama riješenosti provjere $u$ on line sustavu e-učenja MoD

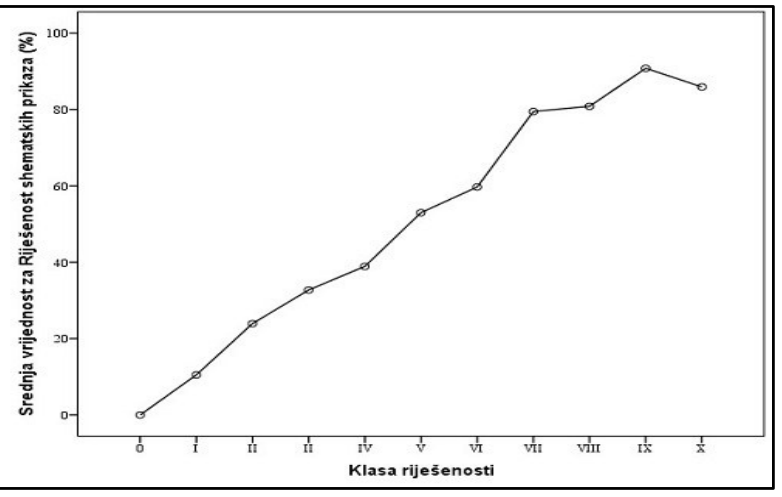

Slika 4. Srednja vrijednost osvojenih bodova za zadatke povezivanja faza u životnim ciklusima odabranih organizama prema klasama riješenosti

\section{Uočene miskoncepcije uz razumijevanje tijeka životnog ciklusa}

Uz zadatak 1. Životni ciklus kokoši kod učenika osnovne škole javlja se miskoncepcija "da jajnici pripadaju muškom spolnom sustavu" (slika 5) koja je vjerojatno uvjetovana narodnim nazivom za testise, zbog čega treba obratiti pažnju pri poučavanju i razjasniti stručnu terminologiju u skladu s narodnim izrazima ako postoje. Ostali pogrešni odgovori sugeriraju moguće miskoncepcije uz životni ciklus kokoši: „iz gameta mejozom nastaju spolni organi“, „oplodnja je vanjska" te "nema brige o potomstvu".

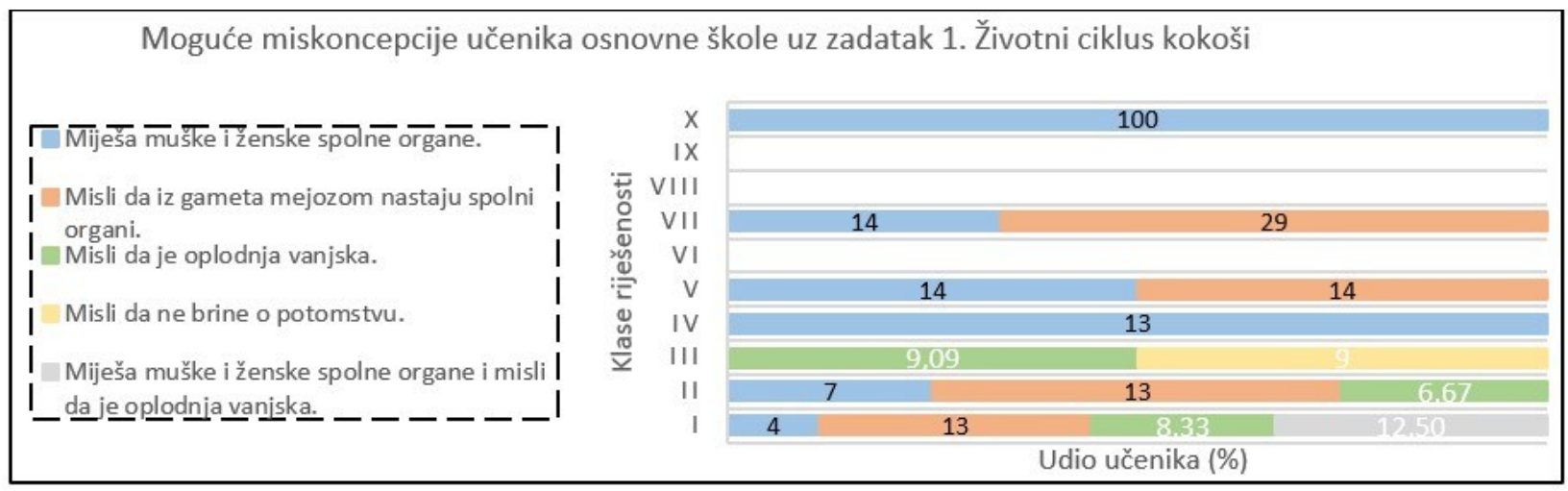

Slika 5. Zastupljenost pojedinih miskoncepcija uz zadatak 1. prema klasama riješenosti

Uz zadatak 2. Životni ciklus jabuke kod učenika osnovne škole javlja se miskoncepcija „plod je odrasla jedinka biljke koja sadrži spolne organe" (slika 6). Kod učenika gimnazije je ta miskoncepcija nešto slabije izražena iako je specifično vezana za arhegonij i anteridij. Zadržava se i miskoncepcija „oplodnja biljaka je vanjska", te se kao moguća miskoncepcija javlja mišljenje da „iz gameta mejozom nastaju spolni organi", ali ne samo kod najslabije uspješnih učenika (slika 6).

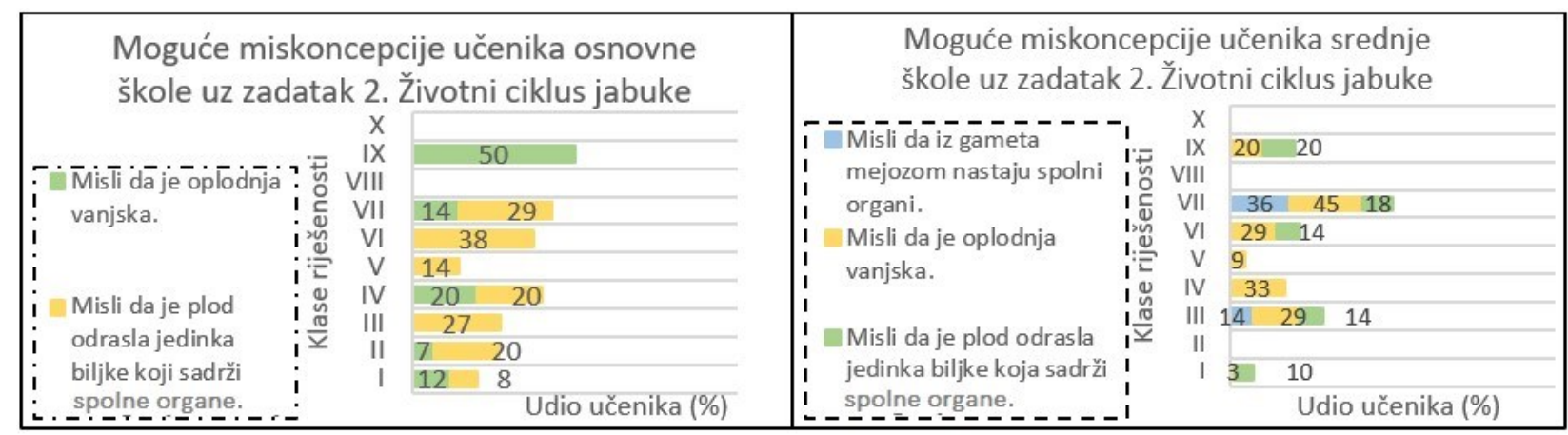

Slika 6. Zastupljenost pojedinih miskoncepcija uz zadatak 2. prema klasama riješenosti 
Uz zadatak 3. Životni ciklus euglene kod učenika osnovne škole i gimnazije javlja se miskoncepcija da je „kod euglene prisutno spolno razmnožavanje“. Možemo govoriti o postojanju miskoncepcije, ali je ona karakteristična za učenike slabijeg uspjeha (slika 7), a takav je rezultat povezan i s velikim brojem neodgovorenih pitanja koja upućuju na nesigurnost učenika u rješavanju zadataka.

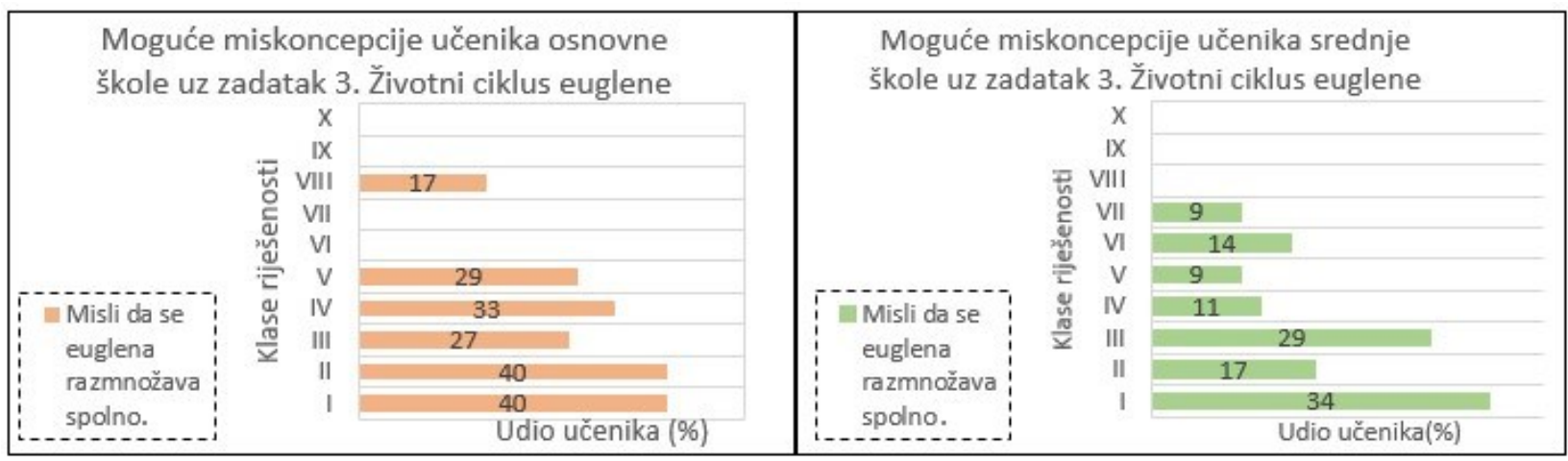

Slika 7. Zastupljenost miskoncepcije uz zadatak 3. prema klasama riješenosti

Uz zadatak 4. Životni ciklus leptira kod učenika osnovne škole javlja se miskoncepcija da „,jajnik pripada muškom spolnom sustavu“ te moguća miskoncepcija „oplodnja je vanjska", dok se kod učenika srednje škole javlja miskoncepcija da „iz gameta mejozom nastaju spolni organi“. Rezultat učenika gimnazije upućuje i na probleme pri učenju i poučavanju, jer se miskoncepcija javlja i kod visokih klasa riješenosti (slika 8).

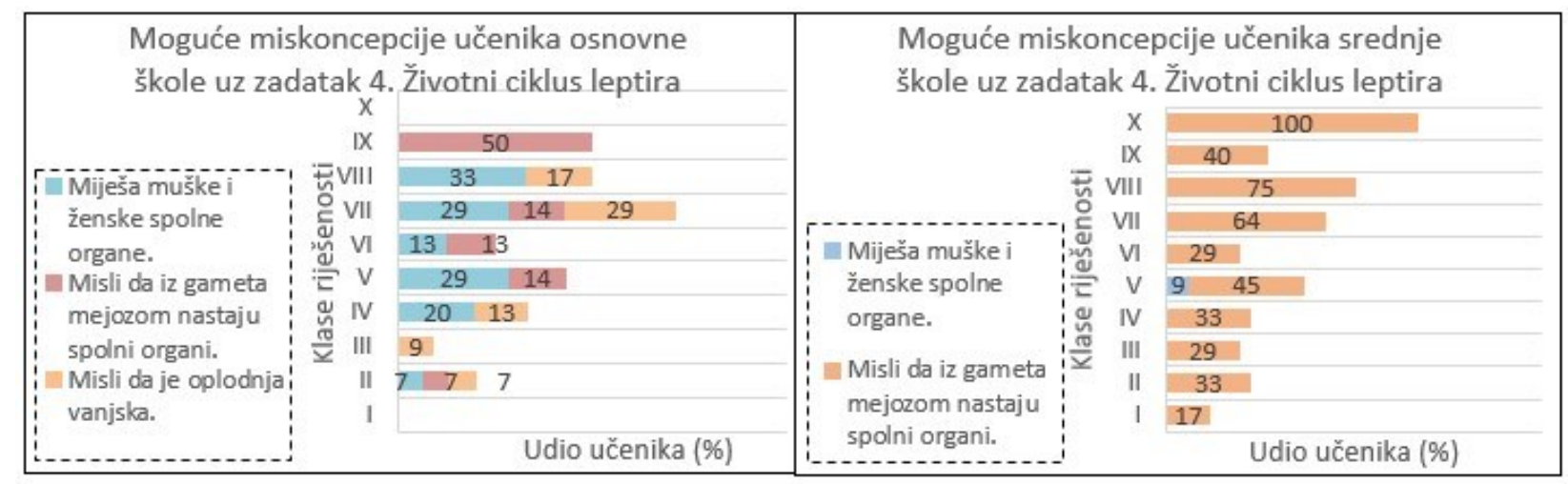

Slika 8. Zastupljenost pojedinih miskoncepcija uz zadatak 4. prema klasama riješenosti

Uz zadatak 5. Životni ciklus žabe kod učenika osnovne škole i gimnazije javlja se miskoncepcija „da je oplodnja unutarnja". Ona se ne mijenja tijekom učenja, jer se javlja kod gotovo svih klasa prema riješenosti provjere u obje razine poučavanja (slika 9).

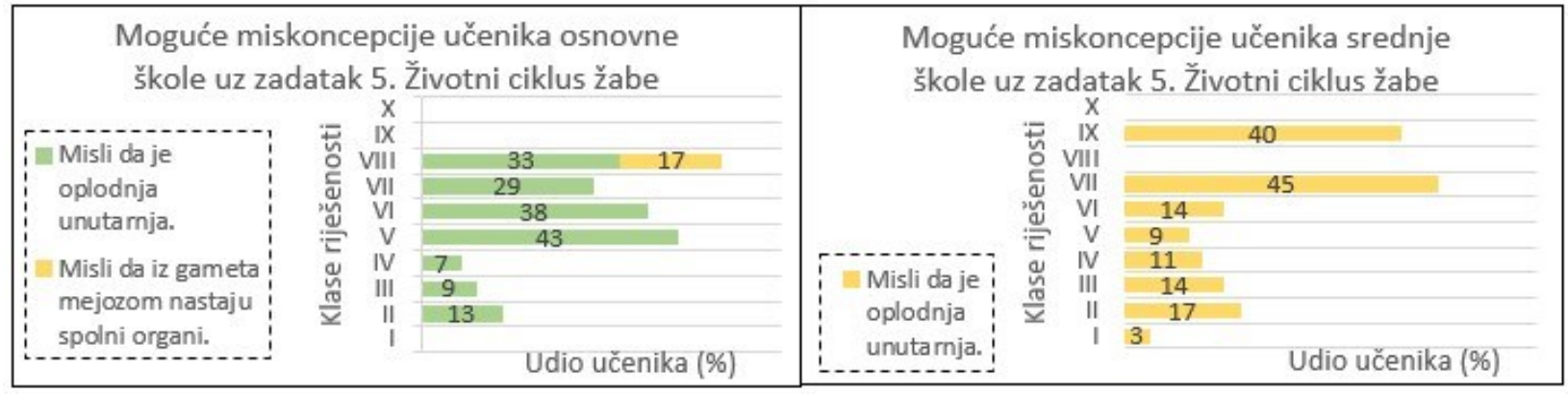

Slika 9. Zastupljenost moguće miskoncepcije uz zadatak 5. prema klasama riješenosti 
Uz zadatak 6. Životni ciklus ježinca kod učenika osnovne škole javlja se miskoncepcija da „iz gameta mejozom nastaju spolni organi", dok se kod učenika gimnazije javlja miskoncepcija "da je oplodnja unutarnja" (slika 10). Izostajanje miskoncepcije kod nižih klase učenika možemo objasniti velikim brojem neodgovorenih pitanja.

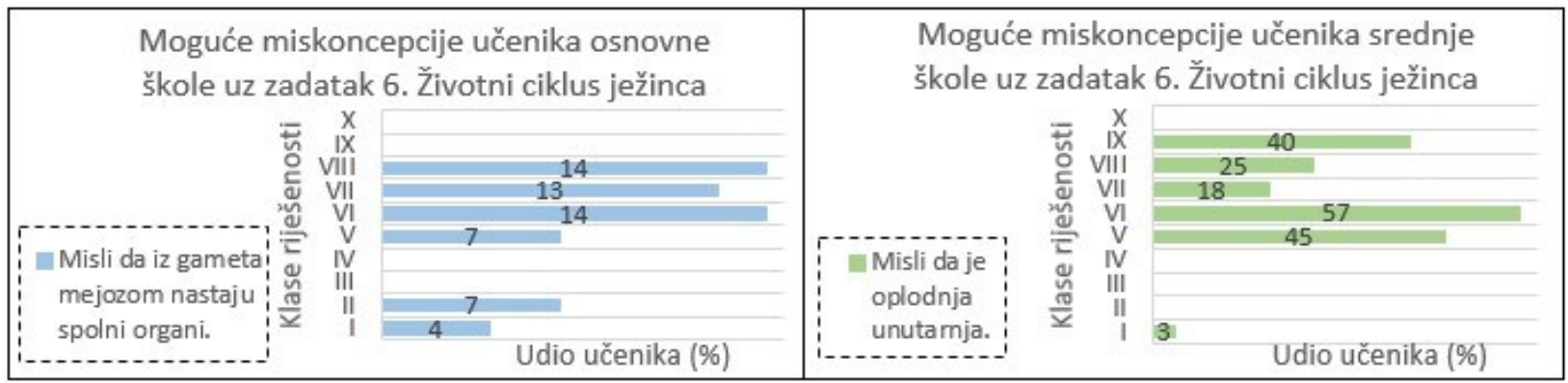

Slika 10. Zastupljenost miskoncepcije uz zadatak 6. prema klasama riješenosti

Uz zadatak 7. Životni ciklus mahovine kod učenika gimnazije javlja se miskoncepcija da kod mahovina "spolne gamete nastaju mejozom". Možemo govoriti o postojanju miskoncepcije izuzev kod najuspješnijih učenika, jer se ona javlja kod gotovo svih klasa prema riješenosti provjere, a izostaje samo kod učenika klase I, II i X (slika 11). Izostajanje miskoncepcije kod učenika klase I i II možemo i ovog puta povezati s velikim brojem neodgovorenih pitanja.

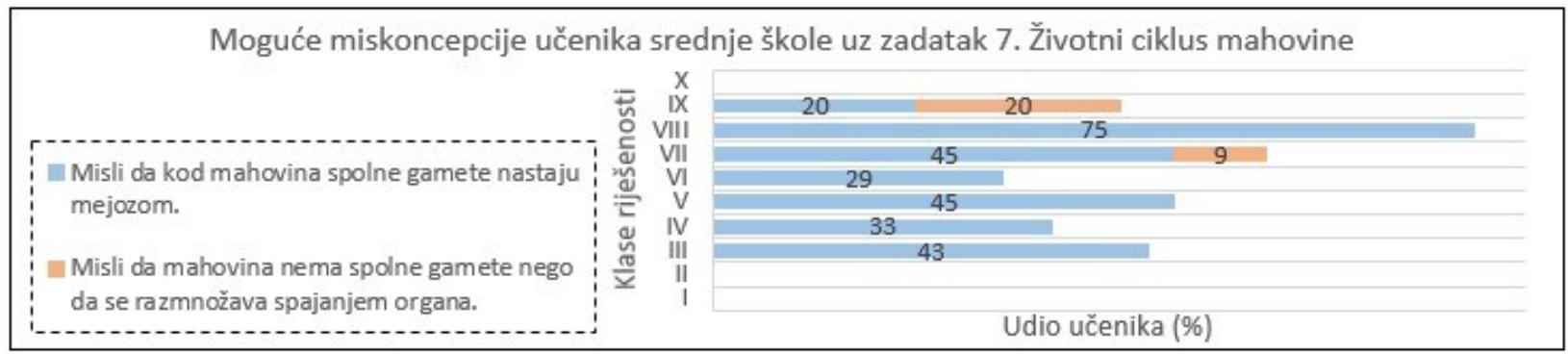

Slika 11. Zastupljenost miskoncepcije uz zadatak 7. prema klasama riješenosti

Uz zadatak 8. Životni ciklus metilja kod učenika osnovne škole javljaju se miskoncepcije "da se svi dvospolci razmnožavaju samooplodnjom" i da "odrasli metilj ulazi/izlazi iz domadara ili međudomadara" (slika 12). Možemo govoriti o postojanju miskoncepcije kojoj protutežu pruža pravilno razumijevanje najuspješnijih, a sporadični izostanak miskoncepcije kod najslabijih učenika ponovno je povezan s velikim brojem neodgovorenih pitanja.

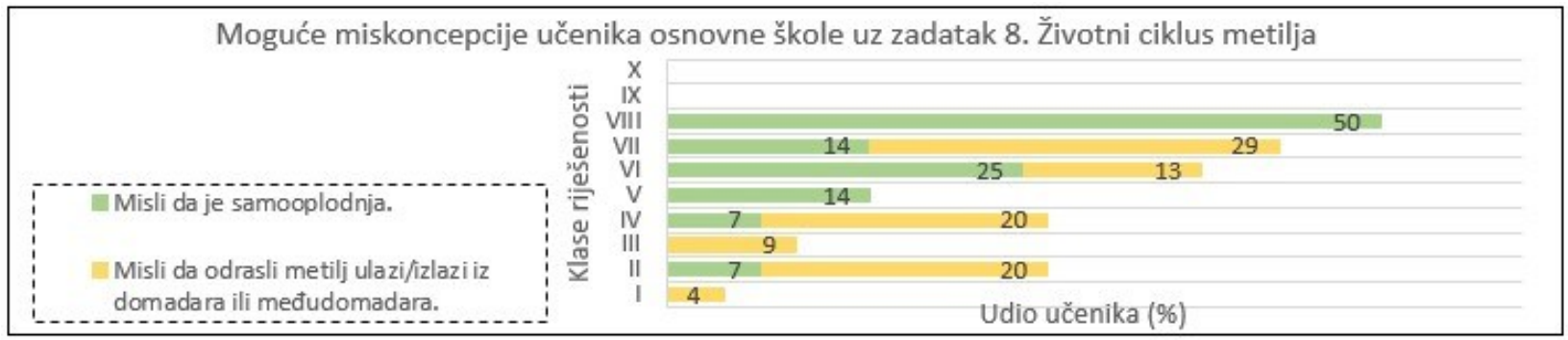

Slika 12. Zastupljenost pojedinih miskoncepcija uz zadatak 8. prema klasama riješenosti

Uz zadatak 11. Životni ciklus gljive kod učenika gimnazije javlja se miskoncepcija da „do oplodnje može doći samo spajanjem gameta, ne i spajanjem cijelih rasplodnih organa" (slika 13). Miskoncepcija se javlja kod učenika viših klasa riješenosti, što upućuje na probleme i u učenju i u poučavanju. 


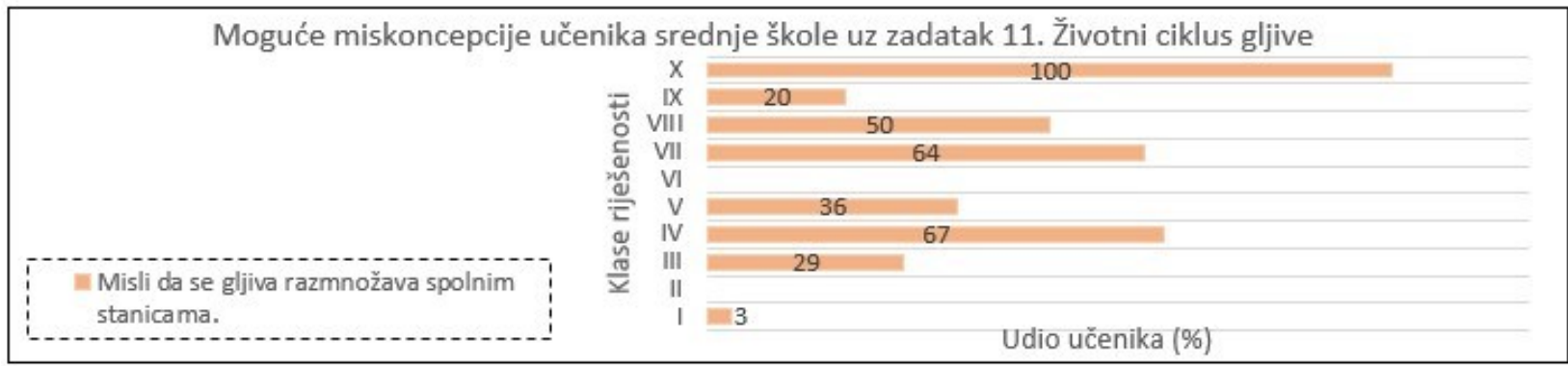

Slika 13. Zastupljenost miskoncepcije uz zadatak 11. prema klasama riješenosti

\section{Usvajanje kumulativnog obrasca životnog ciklusa}

Usporedbom srednjih vrijednosti riješenosti obrasca provjere za pojedini ciklus (tablica 1) može se uočiti da veličina uzorka ne donosi bitne promjene u slijedu usvajanja kumulativnog obrasca životnog ciklusa u primjeni na drugim organizmima. Razlike srednje riješenosti variraju od 0,02 do 0,20 za pojedine cikluse pri čemu se može uočiti da su zadaci bolje riješeni, a razlike riješenosti manje kod onih ciklusa koji se često provjeravaju i koji se često objašnjavaju u udžbenicima i tijekom poučavanja ili su ti organizmi bliži iskustvu učenika (kokoš, jabuka, euglena, leptir, žaba i ježinac). Životni ciklus mahovine najslabije je riješen kod gimnazijskih učenika vjerojatno i zbog toga što je osim faza, spola, dioba trebalo pravilno razmjestiti diploidni, odnosno haploidni broj kromosoma. Životne cikluse metilja i skakavca u kumulativnom prikazu slabo rješavaju (oko 20 \%) obje skupine učenika, s time da gimnazijalci rješavaju za otprilike $10 \%$ bolje od učenika osnovne škole.

Tablica 1. Srednje vrijednosti rješavanja zadataka kumulativne provjere poznavanja životnog ciklusa uzorka i dijela uzorka nakon izuzimanja uočljivo nedosljednog rješavanja zadataka

\begin{tabular}{|c|c|c|c|c|c|c|c|c|c|c|}
\hline & \multicolumn{4}{|c|}{$\begin{array}{c}\text { kumulativna provjera } \\
\text { poznavanja životnog ciklusa }\end{array}$} & \multicolumn{4}{|c|}{$\begin{array}{c}\text { nakon izuzimanja } \\
\text { nedosljednog rješavanja } \\
\text { zadataka }\end{array}$} & \multirow{2}{*}{\multicolumn{2}{|c|}{$\begin{array}{l}\text { Razlika srednjih } \\
\text { vrijednosti }\end{array}$}} \\
\hline & \multicolumn{2}{|c|}{ oš } & \multicolumn{2}{|c|}{ G } & \multicolumn{2}{|c|}{ oš } & \multicolumn{2}{|c|}{ G } & & \\
\hline & M & SD & $\mathrm{M}$ & SD & M & SD & $\mathrm{M}$ & SD & OŠ & $G$ \\
\hline & \multicolumn{2}{|c|}{$N=100$} & \multicolumn{2}{|c|}{$N=100$} & \multicolumn{2}{|c|}{$N=78$} & \multicolumn{2}{|c|}{$N=70$} & os & $G$ \\
\hline Kokoš & 0,64 & 0,48 & 0,84 & 0,36 & 0,72 & 0,45 & 0,93 & 0,26 & $-0,08$ & $-0,08$ \\
\hline Jabuka & 0,36 & 0,48 & 0,63 & 0,49 & 0,44 & 0,50 & 0,77 & 0,42 & $-0,08$ & $-0,15$ \\
\hline Euglena & 0,40 & 0,49 & 0,64 & 0,48 & 0,45 & 0,50 & 0,81 & 0,39 & $-0,05$ & $-0,18$ \\
\hline Leptir & 0,51 & 0,50 & 0,43 & 0,50 & 0,63 & 0,49 & 0,59 & 0,50 & $-0,12$ & $-0,16$ \\
\hline Žaba & 0,53 & 0,50 & 0,50 & 0,50 & 0,65 & 0,48 & 0,69 & 0,47 & $-0,13$ & $-0,19$ \\
\hline Ježinac & 0,40 & 0,49 & 0,36 & 0,48 & 0,50 & 0,50 & 0,50 & 0,50 & $-0,10$ & $-0,14$ \\
\hline Mahovina & 0,22 & 0,41 & 0,08 & 0,28 & 0,27 & 0,45 & 0,11 & 0,32 & $-0,05$ & $-0,03$ \\
\hline Metilj & 0,19 & 0,39 & 0,26 & 0,44 & 0,23 & 0,42 & 0,36 & 0,48 & $-0,05$ & $-0,10$ \\
\hline Skakavac & 0,24 & 0,43 & 0,26 & 0,44 & 0,29 & 0,46 & 0,36 & 0,48 & $-0,06$ & $-0,10$ \\
\hline Riba & 0,36 & 0,48 & 0,28 & 0,45 & 0,45 & 0,50 & 0,26 & 0,44 & $-0,09$ & 0,02 \\
\hline Gljiva & & & 0,19 & 0,39 & & & 0,39 & 0,49 & & $-0,20$ \\
\hline UKUPNO & 0,38 & 0,04 & 0,41 & 0,07 & 0,46 & 0,03 & 0,52 & 0,08 & $-0,08$ & $-0,12$ \\
\hline
\end{tabular}

Zbog velikog broja neodgovorenih zadataka provedena je usporedba rezultata ukupnog uzorka i rezultata učenika koji su korektno riješili zadatke, odnosno koji su ozbiljno shvatili rješavanje zadataka i cijele provjere. Kod učenika koji su ozbiljno shvatili rješavanje provjera uočljivo je da su bolje riješili i najslabije riješene životne cikluse za mahovine. Gimnazijski učenici taj životni ciklus rješavaju najslabije u cijelom ukupnom uzorku $\left(M_{G}=0,08 \pm 0,28\right)$, dok učenici koji su zadacima pristupili korektno taj ciklus rješavaju za 3 \% bolje. Slično je vidljivo i uz životni ciklus gljiva koji zainteresirani učenici rješavaju čak $20 \%$ bolje, u odnosu na slabu riješenost kod gimnazijskih učenika $\left(M_{G}=0,19 \pm 0,39\right)$. Pri rješavanju životnog ciklusa riba gimnazijski učenici zadržavaju riješenost $\left(M_{\text {uzorak }}=0,28 \pm 0,45\right.$ i $M_{\text {korektno }}=0,26 \pm$ 
$0,44)$ dok je kod učenika osnovne škole riješenost porasla kod učenika koji korektno rješavaju cijelu provjeru sa $0,36( \pm 0,48)$ na $0,45( \pm 0,50)$. Takvo opažanje malih razlika uzorka i korektnog poduzorka, usprkos uočenoj potrebi za $20 \%$ do 30 \% korekcije rezultata na osnovi udjela neriješenih zadataka, potvrđuje i zabilježena gotovo potpuna povezanost riješenosti zadataka uz obrazac životnog ciklusa u cijeloj populaciji ispitanika osnovne škole, kao i u poduzorku koji je korektno riješio sve zadatke ( $\rho=$ $0,99 ; p<0,05)$. Slična je povezanost obje skupine učenika s obzirom na riješenost provjere uočena i u slučaju gimnazijskih učenika $(\rho=0,97 ; p<0,05)$. Na taj su način potvrđeni i rezultati interpretacije riješenosti pojedinog zadatka kumulativne provjere, usprkos velikom broju zadataka koje učenici nisu niti pokušali riješiti. Mogući uzrok slabe motivacije za rješavanje kod većeg broja učenika je provođenje provjere u zadnjem tjednu školske godine, kao i mogućnost utjecaja razine pripreme i poticanja motivacije učitelja, a vjerojatno je utjecao i drugačiji oblik provjere kojoj učenici nisu navikli.

Učenici su umjereno bolje povezivali faze u životnom ciklusu svakog sljedećeg organizama u provjeri, uz odstupanja za zadatke u kojima se nisu tražile iste faze u životnom ciklusu (slika 14). Vidljiv je značajan pad u uspješnosti rješavanja zadataka kada u slijedu zadataka dolazi do promjene ispitivanih faza, kao što je slučaj u sljedovima; kokoš i jabuka, euglena i leptir, ježinac i mahovina te skakavac $i$ riba. Pad se može objasniti time da se u svakom sljedećem zadatku od učenika postepeno tražilo sve više informacija. Slabija riješenost u slijedu kokoš i jabuka te ježinac i mahovina ukazuje da učenici imaju veće probleme u određivanju faza životnih ciklusa biljaka. Usprkos velikom broju neriješenih zadataka moguće je sa sigurnošću potvrditi uočenu umjerenu uspješnost usvajanja kumulativnog obrasca životnog ciklusa.
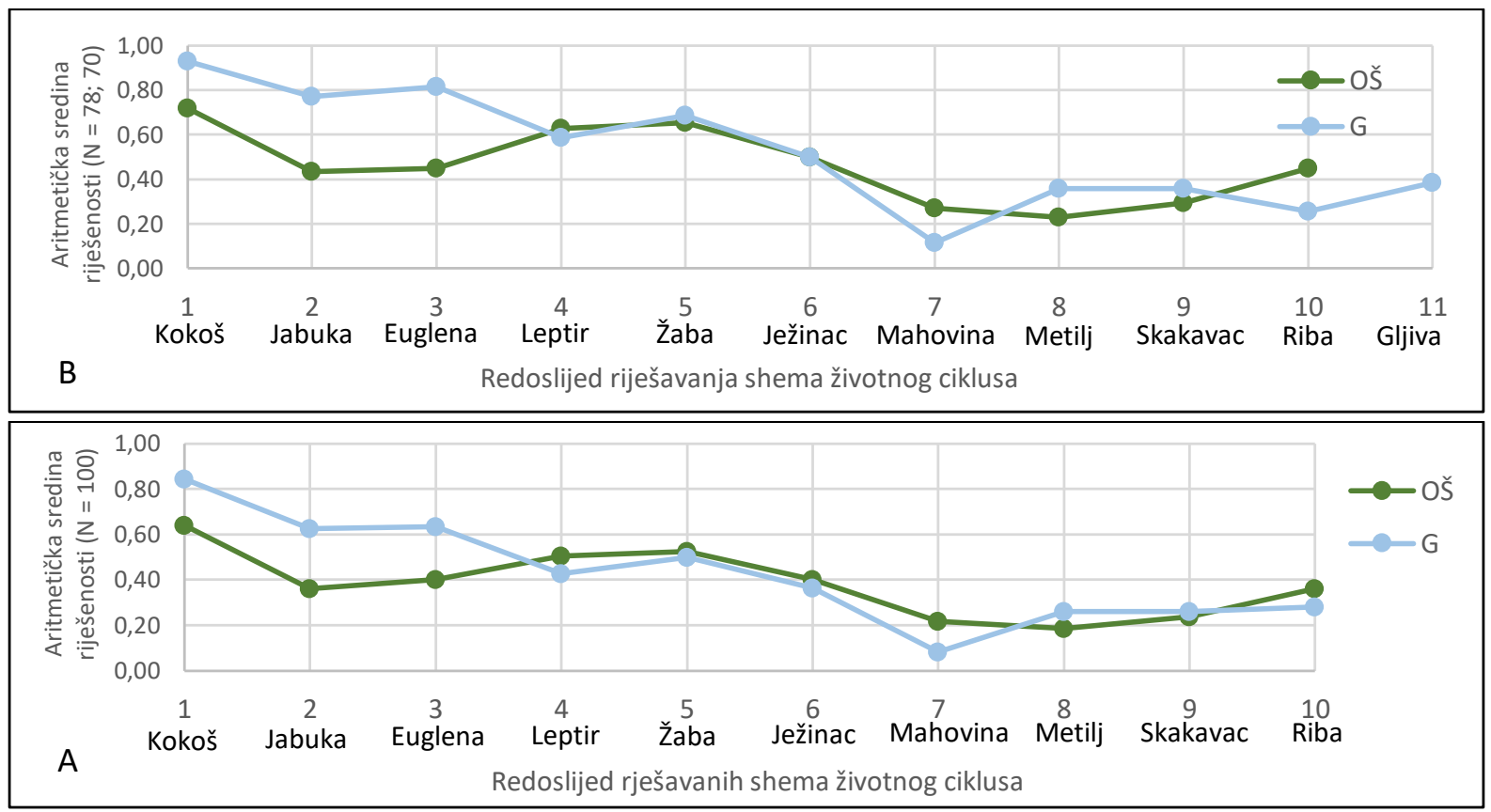

Slika 14. Prosječna riješenost zadataka dopunjavanja faza u životnom ciklusu odabranih organizama cijelog uzorka (A) i korigiranog uzorka (B)

Rezultati multidimenzionalnog (ALSCAL) skaliranja kvadratnih udaljenosti uz nesignifikantne vrijednosti utjecaja postupka (Kruskal stres $=0,068$ ) i dobro utemeljenu proporciju udaljenosti skaliranih podataka (RSQ $=0,98$ ), potvrđuju utjecaj složenosti zadataka u kumulativnom slijedu provjere na riješenost zadataka, kao i utjecaj bliskosti organizama koji se provjeravaju u povezanosti s iskustvom učenika i zahtjevnosti samog zadatka s obzirom na razinu škole (slika 15). Takve utjecaje 
potvrđuju i rezultati Spearmanova koeficijenta korelacije (tablica 2) prema kojima se podupire slijed i zahtjevnost obrasca kumulativnog učenja.

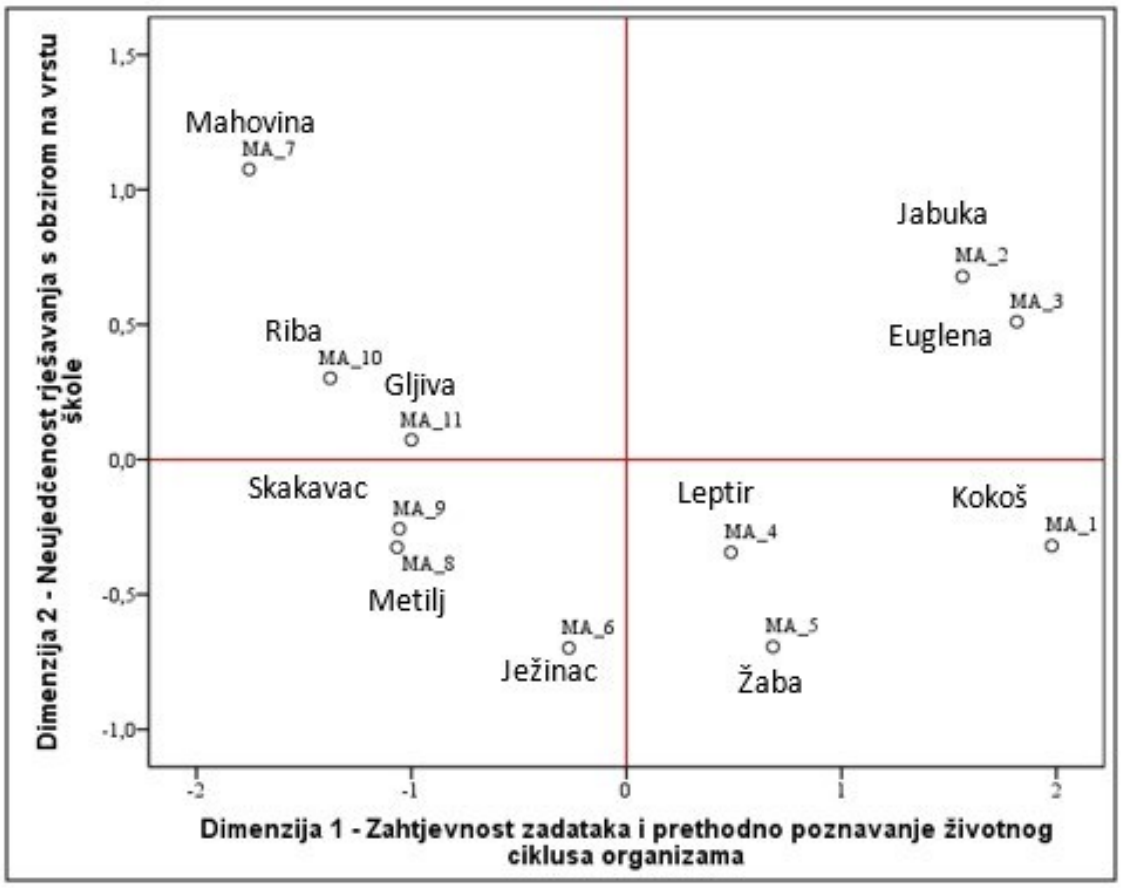

Slika 15. Prosječna veza između riješenosti zadataka životnih ciklusa uz model Euklidske udaljenosti

Tablica 2. Povezanost u rješavanju zadataka kumulativne provjere životnih ciklusa Spearmanovim koeficijentom korelacije ( $\rho)$ s obzirom na riješenost $\left(\mathrm{N}=148, \mathrm{~N}_{\mathrm{glije}}=70\right.$; **signifikantno na 0.01 razini (2-strano), * signifikantno na 0.05 razini (2strano))

\begin{tabular}{|c|c|c|c|c|c|c|c|c|c|c|c|}
\hline & & Kokoš & Jabuka & Euglena & Leptir & Žaba & Ježinac & Mahovina & Metilj & Skakavac & Riba \\
\hline \multirow[t]{2}{*}{ Jobuka } & $\rho$ & $0,358^{* *}$ & & & & & & & & & \\
\hline & $p$ & 0,00 & & & & & & & & & \\
\hline \multirow[t]{2}{*}{ Euglena } & $P$ & $0,281^{* *}$ & $0,377^{* *}$ & & & & & & & & \\
\hline & $p$ & 0,00 & 0,00 & & & & & & & & \\
\hline \multirow[t]{2}{*}{ Leptir } & $\rho$ & $0,338^{* *}$ & $0,465^{* *}$ & $0,230^{* *}$ & & & & & & & \\
\hline & $p$ & 0,00 & 0,00 & 0,00 & & & & & & & \\
\hline \multirow[t]{2}{*}{ Ježinac } & $\rho$ & $0,367^{4 *}$ & $0,165^{*}$ & $0,195^{*}$ & $0,526^{* *}$ & $0,589^{* *}$ & & & & & \\
\hline & $p$ & 0,00 & 0,04 & 0,02 & 0,00 & 0,00 & & & & & \\
\hline \multirow[t]{2}{*}{ Mahovina } & $p$ & 0,01 & 0,06 & $-0,176^{*}$ & $0,187^{*}$ & $0,203^{*}$ & 0,15 & & & & \\
\hline & $p$ & 0,88 & 0,46 & 0,03 & 0,02 & 0,01 & 0,06 & & & & \\
\hline Metilj & $p$ & $0,225^{* *}$ & 0,10 & 0,13 & $0,300^{* *}$ & $0,419^{* *}$ & $0,372^{* *}$ & $0,246^{* *}$ & & & \\
\hline \multirow[t]{2}{*}{ Ribo } & $p$ & $0,243^{* *}$ & 0,07 & 0,12 & $0,340^{* *}$ & $0,436^{* *}$ & $0,409^{* *}$ & $0,377^{* *}$ & $0,391^{* *}$ & $0,627^{* *}$ & \\
\hline & $p$ & 0,00 & 0,39 & 0,15 & 0,00 & 0,00 & 0,00 & 0,00 & 0,00 & 0,00 & \\
\hline \multirow[t]{2}{*}{ Gljiva } & $\rho$ & 0,11 & 0,22 & 0,15 & $0,309^{* *}$ & $0,347^{* *}$ & $0,499^{* *}$ & $0,361^{* *}$ & $0,573^{* *}$ & $0,757^{* *}$ & $0,675^{* *}$ \\
\hline & $p$ & 0,38 & 0,07 & 0,21 & 0,01 & 0,00 & 0,00 & 0,00 & 0,00 & 0,00 & 0,00 \\
\hline
\end{tabular}

Analiza prosječne povezanosti između grupa koje u ovom slučaju predstavljaju zadaci životnih ciklusa prikazani su dendogramom na osnovu kvalitete odgovora u biološkom kontekstu (slika 16). Dendogram potvrđuje grupiranje riješenosti prema jednostavnosti (kokoš i euglena), odnosno složenosti zadatka (riba, mahovina, metilj, gljiva i skakavac). Također se može uočiti povezivanje riješenosti zadataka životnog ciklusa učenicima bliskih organizama o kojima su učili na jednostavan zadatak uz blizak organizam (jabuka), s onima u slučajevima kada se nije inzistiralo na diobama koje prate životni ciklus (leptir, žaba, ježinac). 


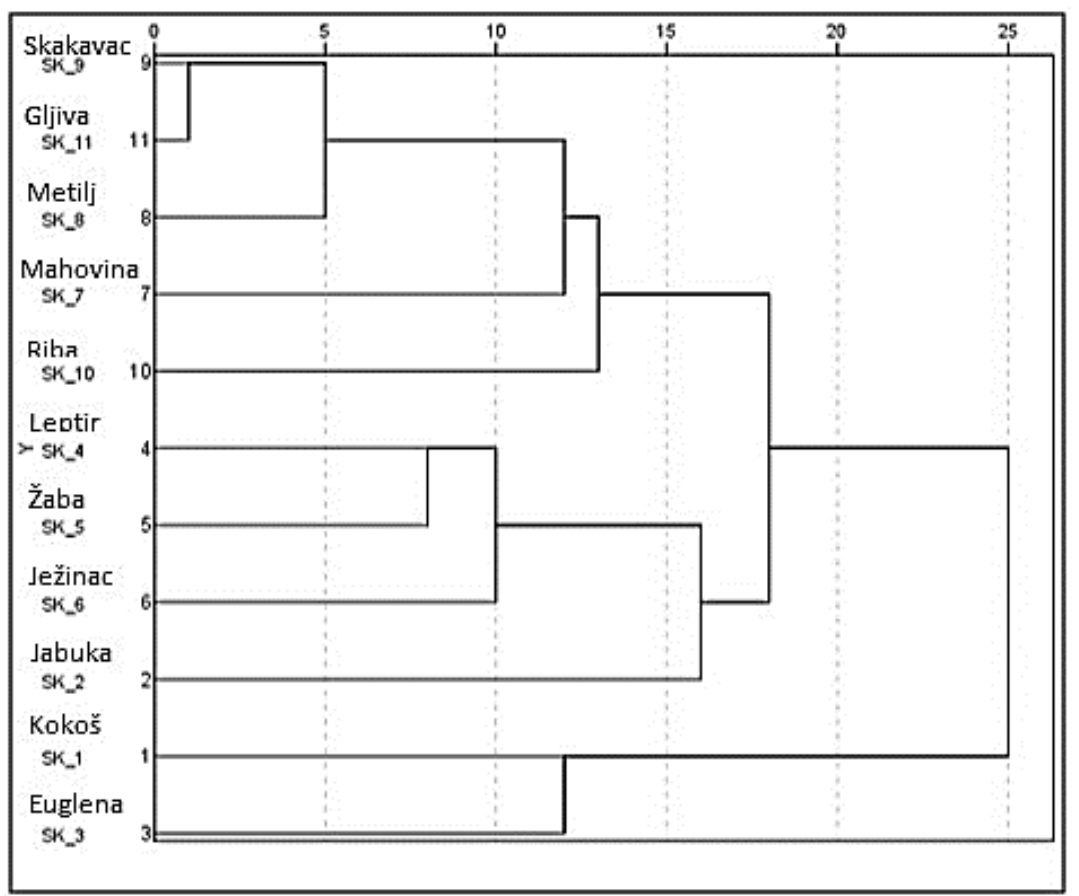

Slika 16. Analiza prosječne povezanosti između rješavanja životnih ciklusa na osnovu kodiranja biološke interpretacije odgovora

\section{RASPRAVA}

Najbolji argument za kumulativno učenje je prema Swarup i sur. (2005) da ljudi stalno koriste analogije za rješavanje problema, uspoređuju i mijenjaju znanje ovisno o kontekstu, što je primijenjeno i pri izradi ove provjere znanja koja je bila učenicima nova, ali je uključivala primjenu znanja uz ranije poučavane organizme. Većinu pitanja učenici su rješavali primjenom znanja, a manji udio reprodukcijom usvojenih činjenica. Pitanja za provjeru u skladu su s nacionalnim planom i programom za osnovnu školu (MZOŠ, 2006) i ispitnim katalogom državne mature (Radanović i sur., 2015).

Analizom svakog učeničkog odgovora na pojedino pitanje utvrđeno je biološko značenje odgovora te su izdvojeni pogrešni odgovori koji se učestalo pojavljuju kod učenika uspoređeni s čestim miskoncepcijama na kraju osnovnoškolskog i srednjoškolskog obrazovanja (Lukša i sur., 2013). Pri tome su učitelji izdvojili sljedeće miskoncepcije koje se pojavljuju na kraju osnovnoškolskog obrazovanja (Lukša i sur., 2013): "ne razlikuju mitozu i mejozu”, "ne povezuju mitozu i mejozu s tjelesnim i spolnim stanicama”, "ne razumiju pojam životni uvjeti" i "ne povezuju biologiju sa svakodnevnim životom". Izdvojene miskoncepcije koje se pojavljuju na kraju srednjoškolskog obrazovanja su(Lukša i sur., 2013): „ne razlikuju pojmove sporofit i gametofit", „miješaju pojmove oprašivanje i oplodnja“ i „miješaju pojmove sporofit, sporangij, spora“. Izdvojene su i miskoncepcije koje se pojavljuju i na kraju osnovnoškolskog i srednjoškolskog obrazovanja (Lukša i sur., 2013): „ne razlikuju broj kromosoma u tjelesnim i spolnim stanicama“, "smatraju da se kromosomi udvostručuju u mitozi“ $\mathrm{i}$ „ne razlikuju pojmove hranidbeni lanac i mreža“.

U zadacima popunjavanja faza životnih ciklusa odabranih organizama učenici osnovne škole najviše problema imali su s određivanjem muških i ženskih spolnih organa. Miskoncepcija se pojavljuje kroz više zadataka povezivanja faza u životnom ciklusu odabranih organizama te kod većine klasa riješenosti provjere. Međutim, učitelji je nisu izdvojili kao očekivanu miskoncepciju s kojom se susreću na kraju osnovnoškolskog obrazovanja (Lukša i sur., 2013). Objašnjenje možemo potražiti u osmom razredu 
osnovne škole kada učenici obrađuju spolni sustav čovjeka i detaljnije opisuju proces oplodnje i građu muških i ženskih spolnih organa. Istraživanje je provedeno na kraju sedmog razreda osnovne škole, pa je miskoncepcija prisutna kod velikog broja učenika. Može se pretpostaviti da se miskoncepcija utvrđuje i ispravlja u osmom razredu osnovne škole. Veliki broj učenika osnovne škole smatra da plod biljkama služi za oprašivanje, što odgovara rezultatima Lukša i sur. (2013) te predviđanjima učitelja koji su izdvojili miskoncepciju „miješaju pojmove oprašivanje i oplodnja". Zanimljivo je da ne možemo govoriti o postojanju miskoncepcije kod učenika gimnazije jer se ono pojavljuje kod manjeg broja učenika prema klasama riješenosti provjere. Učitelji su izdvojili ovu miskoncepciju za učenike na kraju srednjoškolskog obrazovanja, ne i na kraju osnovnoškolskog obrazovanja. Objašnjenje možemo potražiti u manjem uzorku učenika s kojima se susreću učitelji, odnosno često pojavljivanje istih miskoncepcija u istom razredu ili školi zbog vršnjačkog utjecaja na pojavu miskoncepcija (Bahar, 2003). Učenici obje razine školovanja smatraju da se „euglena razmnožava spolnim načinom“. Možemo govoriti o postojanju miskoncepcije jer se pojavljuje kod velikog broja učenika prema klasama riješenosti provjere. lako nije izdvojena kao očekivana miskoncepcija na kraju osnovnoškolskog ili srednjoškolskog obrazovanja, uočeno je da se ne uklanja niti na kraju drugog razreda gimnazije. Miskoncepcija se može povezati s generalizacijom spolnog razmnožavanja velikog broja životinja. lako su učenici osnovne škole i gimnazije griješili u određivanju procesa mejoze i mitoze ne možemo govoriti o postojanju miskoncepcije "ne razlikuje mitozu i mejozu“ Lukša i sur. (2013) već o problemima pri učenju i memoriranju što odgovara rezultatima Golubić i sur. (2017). Miskoncepcija nije dovoljno specifična da bi se utvrdilo njezino postojanje, već se jedino može utvrditi s kojim biološkim konceptima učenici imaju problema. Nije utvrđeno postojanje očekivane miskoncepcije "ne razlikuju broj kromosoma u tjelesnim i spolnim stanicama" Lukša i sur. (2013) kod učenika gimnazije. lako su učenici imali problema s određivanjem broja kromosoma u zadacima povezivanja faza u životnom ciklusu ne možemo govoriti o postojanju miskoncepcije jer se ona ne pojavljuje kod većine klasa riješenosti provjere, odnosno pojavljuje se samo kod nižih klasa riješenosti što upućuje na probleme pri učenju i razumijevanju biološkog sadržaja. Navedena predviđena miskoncepcija Lukša i sur. (2013) može se povezati s miskoncepcijama "smatraju da se kromosomi udvostručuju u mitozi“ $\mathrm{i}$ „ ne povezuju mitozu i mejozu s tjelesnim i spolnim stanicama" za koje također nije utvrđeno postojanje što se slaže $s$ rezultatima Golubić i sur. (2017). Ukupno možemo reći da učenici imaju razvijeno dobro konceptualno razumijevanje procesa mejoze i mitoze, što potvrđuje da su učitelji koncepte diobe prepoznali kao vrlo važnim i u svojem ih poučavanju nastoje dobro objasniti, ali i provjeriti sposobnost primjene znanja učenika i njihovo razumijevanje. Ovim je istraživanjem kao iznimka utvrđena miskoncepcija učenika obje razine školovanja $d a$ „iz spolnih gameta mejozom nastaju spolni organi“ koja se ne može svrstati u niti jednu predviđenu miskoncepciju učitelja Lukša i sur. (2013) zbog svoje specifičnosti. U navedenom slučaju možemo govoriti o postojanju miskoncepcije, jer se ona pojavljuje kod velikog broja učenika obzirom na klase riješenosti provjere, a zadržava se i tijekom daljnjeg školovanja.

Utvrđeno je postojanje miskoncepcije „ne razumiju pojam životni uvjeti“ kod učenika osnovne škole i gimnazije što odgovara istraživanju Lukša i sur. (2013). Odgovori ukazuju da učenici ne povezuju životne uvjete staništa s načinom oplodnje i brojnošću potomaka. Učenici osnovne škole, ali i gimnazije ne povezuju životne uvjete staništa, način života, građu i funkciju organizma sa specifičnostima njegovog životnog ciklusa. S obzirom da se krivo poimanje te povezanosti pojavljuje kod velikog broja učenika prema klasama riješenosti, možemo govoriti o postojanju miskoncepcije Primjerice, učenici ne povezuju životne uvjete staništa žabe $s$ vanjskim načinom oplodnje. $U$ navedenim konceptima pojavljuju se i problemi kod određivanja brojnosti potomaka različitih kralježnjaka i nametnika. Takav 
rezultat naglašava važnost potrebe većeg povezivanja bioloških koncepata u kontekstu specifičnih organizama. Veliki broj učenika imao je problema s određivanjem faza u životnom ciklusu metilja. Utvrđeno je postojanje miskoncepcija kod učenika osnovne škole da se "metilj razmnožava samooplodnjom" i da "odrasli metilj ulazi/izlazi iz domadara ili međudomadara", dok se kod učenika gimnazije one zadržavaju kod manjeg broja učenika obzirom na klasu riješenosti pa ne možemo govoriti o postojanju miskoncepcije. Pogrešno razmišljanje ukazuje na konceptualno nerazumijevanje životnog ciklusa metilja, jer učenici ne prepoznaju metilja kao organizam koji stvara veliki broj potomaka. Navedene miskoncepcije nisu predviđene od strane učitelja Lukša i sur. (2013), vjerojatno zbog svoje specifičnosti za životni ciklus metilja. Ne može ih se primijetiti kroz različita pitanja već samo pitanjima specifično vezanima za životni ciklus metilja ili sličnog nametnika s aspekta života drugih organizama. Utvrđeno je postojanje miskoncepcije „ne razumiju izmjenu generacija gljiva“ kod učenika gimnazije. Jako mali broj učenika je točno označio faze u životnom ciklusu gljive što ukazuje na ukupno konceptualno nerazumijevanje životnog ciklusa gljive. Nije utvrđeno postojanje miskoncepcije Lukša i sur. (2013) "miješaju pojmove sporofit, sporangij i spora" te "ne razlikuju pojmove sporofit i gametofit" kod zadatka popunjavanja faza u životnom ciklusu mahovine. Kao što ističe Garašić (2012) kod problema razlikovanja pojmova "mitoze i mejoze", "sporofita, sporangija i spore“ kao i pojmova „gametofit i sporofit“, moguće je da odgovor nije rezultat nerazumijevanja, već miješanje i zaboravljanje stručnih pojmova. Nevezano uz pojmove učenici nisu razlikovali sliku gametofita i sporofita što upućuje na nedovoljnu vizualizaciju bioloških sadržaja od strane učenika i nedovoljnu upotrebu slika, videa i animacija od strane učitelja. Pogrešan odabir slika za pojedine faze unutar životnog ciklusa upućuje da učitelji nisu u poučavanju koristili univerzalne obrasce odnosno da na njih nisu upućivali učenike kako bi oni uočili zajedničke principe životnih ciklusa, ali i po čemu se pojedini ciklusi različitih predstavnika skupina međusobno razlikuju. Takav rezultat signalizira da je pri učenju i poučavanju izostala upotreba grafičkih organizatora znanja što je u konačnici uzrokovalo slabije snalaženje učenika u univerzalnom obrascu. Takav zaključak podupire i Maton (2009) koji naglašava da učenici trebaju razvijati određene vještine i reflektivno razmišljati o njihovoj primjeni u svakodnevnom kontekstu kako bi mogli uspješno prenijeti svoje znanje iz jednog koncepta u drugi. U skladu s tim objašnjenjem učenike treba poučavati na način da uvide smislenost učenja i njegovu primjenjivost, a što se može ostvariti primjenom grafičkih organizatora znanja kao okosnice učenja različitih principa, pa tako i onog na kojem počivaju životni procesi različitih organizama. Pri tome trebalo bi učenicima omogućiti upoznavanje organizama o kojima uče uz promatranje i istraživanje, ako ne u prirodnom okruženju onda na znanstveno utemeljenim istraživačkim aktivnostima u simulacijama vezanim uz životni ciklus pojedinog organizma.

Ukupno, možemo govoriti o slaganju dobivenih rezultata s ranijim istraživanjima, u kojima se pojavljuje mnogo problema i miskoncepcija uz koncept Životni ciklusi (Lukša i sur., 2016). Učenici su imali najviše problema u određivanju faza u životom ciklusu biljaka i gljiva, što se može povezati s manjom razinom interesa učenika za proučavanjem ovih živih bića kako naglašava Garašić (2012). S obzirom da se mnogi ovdje utvrđeni problemi i miskoncepcije pojavljuju podjednako na kraju osnovne škole i u gimnaziji kako navodi i Lukša (2011), uzroke možemo potražiti u tradicionalnom načinu poučavanja, izostanku iskustvenog učenja i povezivanja nastavnih sadržaja tijekom poučavanja (Garašić i sur., 2018), ali i u tradicionalnom načinu provjeravanja usvojenosti bioloških koncepata. Veliki broj učenika nije odgovorio na većinu pitanja, što upućuje na nesigurnost učenika u primjeni principa i obrazaca životnih ciklusa različitih organizama u zadacima u kojima se traži razmišljanje. Takav zaključak potkrjepljuje zaključak Ristić Dedić i sur. (2011) koji su utvrdili da je i tadašnji ispit državne mature iz biologije 
prezasićen zadacima kojima se mjeri poznavanje i dosjećanje, a takvi ispiti odgovaraju prevladavajućem načinu poučavanja i učenja biologije. Na rješavanje i ozbiljnost pristupa rješavanju znatno je utjecala i priprema učenika za rješavanje, koje su učitelji vrlo različito proveli. Učenici osnovne škole provjeru su rješavali na satu biologije ili informatike, dok su učenici srednje škole provjeru ponajviše rješavali kod kuće. Također može se povezati s vremenom provođenja istraživanja, odnosno krajem školske godine kada učenici imaju drugih obaveza i nisu dovoljno motivirani i strpljivi za rješavanje dodatne provjere. Zbog uočenih problema pri provedbi, rezultati ovog istraživanja mogu se interpretirati u smislu osnovne orijentacije prema problemu razumijevanja koncepta Životni ciklusi. Rezultati ukazuju na potrebu detaljnijeg i kontinuiranog istraživanja u kojem bi se obuhvatili učenici svih razina školovanja, kako bi se moglo provjeriti hoće li se, kako i kada će se uočene miskoncepcije ispraviti tijekom vertikale učenja biologije.

Culyer (1982) naglašava da je neuspješno poučavanje također kumulativno, što je u skladu s rezultatima ovog istraživanja. Rezultat generalno ukazuje na slab uspjeh primjene kumulativnog obrasca na novim primjerima tijekom provjere, što se ne slaže s rezultatima Heron i Craik (1964) te Ozogul i sur. (2012) gdje je utvrđena uspješnost kumulativnog učenja. Treba istaknuti i da se u ovom slučaju nije radilo o potpunom obliku kumulativnog učenja u kojem učitelji vode učenika tijekom učenja i sistematizacije kumulativnog obrasca na novim primjerima, već se temeljilo na provjeri znanja učenika i njihova razumijevanja primjenom obrasca i usložavanjem zadataka uz obrazac kumulativne provjere znanja. Međutim, rezultate istraživanja možemo povezati s rezultatima Nathanson i sur. (2004) i Jung (1964) gdje je utvrđeno da kumulativno učenje nema veliki uspjeh kod učenika koji su tijekom školovanja poučavani tradicionalno i koji su prihvatili takav način učenja. Učenici su upoznati sa svim ispitivanim životnim ciklusima odabranih organizama na nastavi biologije, te primjenjuju svoje prethodno znanje za rješavanje zadataka zanemarujući nadogradnju i povezanost univerzalne sheme životnog ciklusa. Rezultati istraživanja mogu se objasniti slabom primjenom konceptualnog i kumulativnog načina učenja i provjeravanja u nastavi biologije što nalazi potkrjepu u zaključku koji je istaknuo Maton (2013) da poučavanje često uključuje ponavljajući uzorak primjera koji ovise o kontekstu uz pojednostavljenja prikaza znanstvenih činjenica. Na rezultate je mogao utjecati i drugačiji način provjere bioloških koncepata putem on line platforme zbog njenih specifičnosti. Korištenje online platforme moglo je također utjecati i na veliki broj neodgovorenih pitanja što direktno utječe na prosječnu riješenost provjere. Upravo neodgovorena pitanja upućuju na dominantan tradicionalni oblik poučavanja i provjere znanja pa učenici teško prihvaćaju zadatke u kojima se od njih traži razmišljanje uz utvrđivanje obrazaca i principa odvijanja procesa. Veliki utjecaj na probleme u izgradnji koncepata ima i izostanak primjene grafičke sistematizacije, što su utvrdili i Merkley i Jefferies (2000), a koja će učenicima omogućiti kumulativno uočavanje principa i sistematizaciju uzročno-posljedičnih veza tijekom životnog ciklusa pojedinog organizma. Yew i sur. (2011) naglašavaju da iako se kumulativno učenje pokazalo uspješnim u mnogim aspektima ljudskog života, do danas su rijetki primjeri kumulativnog poučavanja u učionici biologije, kao što su to predložili Freiman i sur. (2001). Sami nastavnici mogu pospješiti kumulativno učenje i provjeravanje, ako potaknu korištenje grafičkih organizatora za podršku kumulativnog učenja usprkos ograničenja nastavnog programa.

\section{ZAKLJUČAK}

Prema provedenom istraživanju moguće je zaključiti:

Učenici osnovne škole i gimnazije pokazuju podjednako razumijevanje životnih ciklusa različitih organizama obzirom na opseg ispitivanog sadržaja. 
Utvrđeno je postojanje problema kod usvojenosti koncepta Životni ciklusi te su uočene karakteristične miskoncepcije koje su uvjetovane poistovjećivanjem prikaza i naziva na osnovu svakodnevnog govora, zamjenom slijeda procesa i naziva te nerazumijevanjem nedovoljno bliskih organizama, njihova načina života i karakteristika.

Veliki broj učenika nije odgovorio na većinu pitanja, što upućuje na nesigurnost učenika u primjeni principa i obrazaca životnih ciklusa različitih organizama.

Pogrešno odabiranje slika pojedinih faza životnog ciklusa upućuje na izostanak korištenja grafičkih organizatora znanja kao i nedovoljnu iskustvenu podršku i korištenje živih preparata, modela, slika i videa u nastavi biologije.

Učenici osnovne škole, ali i gimnazije ne povezuju životne uvjete staništa, način života, građu i funkciju organizma sa specifičnostima njegovog životnog ciklusa, što ukazuje na važnost većeg povezivanja bioloških koncepata u kontekstu specifičnih organizama.

Na rješavanje zadataka vezanih uz životni ciklus u kumulativnom slijedu učenja utječe složenosti zadataka kao i bliskosti organizama koji se provjeravaju u povezanosti s iskustvom učenika i zahtjevnosti samog zadatka s obzirom na razinu škole.

\section{METODIČKI ZNAČAJ}

Uspješnost usvajanja životnih ciklusa različitih organizama ne bi se trebala provjeravati ispitivanjem stručnih pojmova i memoriranim slijedom događaja, već zadacima u kojima se provjerava razina razumijevanja, kao i usporedbe i analize životnih ciklusa različitih vrsta organizama. Problem se javlja kod planiranja nastave usmjerene na sadržaj vezan isključivo za taj sat i ne dovođenja u vezu ranije obrađenih nastavnih sadržaja. Također, problem se javlja kod planiranja provjera, gdje se naglasak stavlja na reprodukciju nastavnih sadržaja i od učenika se ne traže više kognitivne razine. Veliki je problem i to što u provjerama često nisu uključeni ranije obrađeni sadržaji na način da se provjerava njihova povezanost i nadogradnja novim sadržajima, već se u pravilu samo provjeravaju sadržaji konkretne teme navedeni u udžbenicima. Tijekom nastavnog procesa trebali bi se koristiti slikama, video materijalima i modelima kako bi se učenicima približio sadržaj te ga treba dovoditi u vezu s prethodnim usvojenim znanjima, inzistirajući od učenika da uspoređuju i analiziraju životne cikluse pojedinih organizama korištenjem grafičkih organizatora znanja. Učitelji imaju slab uvid u kojoj mjeri učenici doista razumiju koncept Životni ciklusi, što ima za posljedicu loše određivanje predkoncepcija i mogućih miskoncepcija na kojima bi trebali temeljiti svoje planiranje daljnjeg poučavanja, ali i provjere znanja. Učitelji bi trebali preuzeti inicijativu i pristupiti kumulativnom načinu poučavanja životnih ciklusa, kao i drugih nastavnih sadržaja gdje treba naglasiti konceptualno povezivanje uz nadogradnju ishodišnog univerzalnog obrasca.

\section{ZAHVALA}

Zahvaljujemo se svim učiteljima i učenicima koji su sudjelovali u istraživanju: Osnovna škola "Antun Gustav Matoš" Vinkovci, Osnovna škola Jabukovac Zagreb, Osnovna škola Rapska Zagreb, Osnovna škola Sesvete Zagreb, Osnovna škola Sesvetski Kraljevec Zagreb, Gimnazija A. G. Matoš Zabok, Gimnazija Ivana Zakmardija Dijankovečkoga Križevci, Gimnazija Josipa Slavenskog Čakovec, IX. gimnazija Zagreb, V. gimnazija Zagreb, X. gimnazija Zagreb, XI. gimnazija Zagreb, XV. gimnazija Zagreb i XVIII. Gimnazija Zagreb.

Statistički proračuni izrađeni su pomoću programskog paketa SPSS 22 (IBM, 2013) susretljivošću djelatnika Centra za istraživanje i razvoj obrazovanja (CIRO) Instituta za društvena istraživanja u Zagrebu (IDIZ), na čemu im se najiskrenije zahvaljujemo.

\section{LITERATURA}

American Association for the Advancement of Science (AAAS) 2010. Vision and Change: A Call to Action, Washington, DC. http://visionandchange.org/files/2010/03/VC report.pdf, preuzeto 23.4. 2018. 
Bahar, M. 2003. Misconceptions in biology education and conceptual change strategies. Educational Sciences: Theory \& Practice, 3(1), 55-64.

Bharadwaj, K. K., Kandwal, R. 2008. Cumulative learning techniques in production rules with fuzzy hierarchy (PRFH) system. Journal of Experimental and Theoretical Artificial Intelligence, 20(2), 111-132. https://doi.org/10.1080/09528130701524117

Culyer, R. C. 1982. Cumulative teaching, better learning. Academic Therapy, 17(5), 537-542.

Freiman, T., Niederweis, B., Ludwig, J. 2001. Kumulatives lernen mithilfe schematischer Darstellungen. Praxis der naturwissenschaften, Biologie in der schule, 7-14.

Furby, L. 1972. Cumulative learning and cognitive development. Human development, 15(5), $265-286$.

Gagné, R. M. 1985. The Conditions of Learning and Theory of Instruction. New York: Holt, Rinehart, and Winston, 361 str.

Garašić, D. 2012. Primjerenost biološkog obrazovanja tijekom osnovnog i gimnazijskog školovanja: doktorska disertacija Prirodoslovno-matematički fakultet Sveučilišta u Zagrebu. 348 str.

Garašić, D., Radanović, I., Lukša, Ž. 2018. Osvrt na aktualne nastavne programe učenja biologije. Napredak: časopis za pedagogijsku teoriju i praksu. 159 (1-2), 179-194.

Golubić, M., Begić, V., Lukša, Ž., Korać, P., Radanović, I. 2017. Razumijevanje životnog ciklusa i oplodnje tijekom učenja biologije u osnovnoj školi. Educatio biologiae, 3(1), 76-99. https://hrcak.srce.hr/192683

Heron, A., Craik, F. 1964. Age differences in cumulative learning of meaningful and meaningless material. Scandinavian Journal of Psychology, 5(1), 209-217.

Hopkins, W.G. 2000. A new view of statistics. Internet Society for Sport Science. http://www.sportsci.org/resource/stats/ preuzeto 25.05.2018.

Huang, J. C., Frey, B. J. 2009. Structured ranking learning using cumulative distribution networks. Advances in Neural Information Processing Systems, 697-704.

Jung, J. 1964. A cumulative method of paired-associate and serial learning. Journal of Memory and Language, 3(4), $290-299$.

Lukša, Ž. 2011. Učeničko razumijevanje i usvojenost osnovnih koncepata u biologiji: doktorska disertacija. Prirodoslovnomatematički fakultet Sveučilišta u Zagrebu. 317. str.

Lukša Ž., Radanović, I., Garašić, D. 2013. Očekivane i stvarne miskoncepcije učenika u biologiji. Napredak: časopis za pedagogijsku teoriju i praksu. 154(4), 527-548.

Lukša, Ž., Radanović, I., Garašić, D., Sertić Perić, M. 2016. Misconceptions of Primary and High School Students Related to the Biological Concept of Human Reproduction, Cell Life Cycle and Molecular Basis of Heredity. Journal of Turkish Science Education (TUSED). 13(3), 143-160.

Maton, K. 2009. Cumulative and segmented learning: Exploring the role of curriculum structures in knowledge-building. British journal of sociology of education, 30(1), 43-57, https://doi.org/10.1080/01425690802514342

Maton, K. 2013. Making semantic waves: A key to cumulative knowledge-building. Linguistics and Education, $24(1), 8-22$. Merkley, D. M., Jefferies, D. 2000. Guidelines for implementing a graphic organizer. The reading teacher, 54(4), $350-357$.

MZOŠ 2006. Nastavni plan i program za osnovnu školu. Ministarstvo znanosti, obrazovanja i sporta Zagreb. Nakladnik Primorac, D., urednici Vican, D. i Milanović Litre, I.

Nathanson, C., Paulhus, D. L., Williams, K. M. 2004. The challenge to cumulative learning: Do introductory courses actually benefit advanced students?. Teaching of Psychology, 31(1), 5-9.

Ozogul, G., Johnson, A. M., Moreno, R., Reisslein, M. 2012. Technological literacy learning with cumulative and stepwise integration of equations into electrical circuit diagrams. IEEE Transactions on Education, 55(4), 480-487. https://doi.org/10.1109/TE.2012.2190072

Radanović I., Lukša Ž., Pongrac Štimac Z., Garašić D., Bastić M., Kapov S., Kostanić LJ., Sertić Perić M., Toljan M. 2017. Sadržajna i metodološka analiza ispita državne mature iz Biologije u školskoj godini 2015./2016. NCVVO Zagreb 212 str.

Radanović, I., Garašić, D., Lukša, Ž., Pongrac Štimac, Z., Bastić M., Kapov S., Karakaš D., Lugarić S., Vidović M. 2015. Ispitni katalog za Državnu maturu iz Biologije. NCVVO, Zagreb.

Radanović I., Garašić D, Lukša Ž., Ristić-Dedić Z., Jokić B., Sertić Perić M. 2016. Understanding of photosynthesis concepts related to students' age. In. Lavonen J., Juuti K., Lampiselkä J., Uitto A. \& Hahl K. (Eds.), Electronic Proceedings of the ESERA 2015 Conference. Science education research: Engaging learners for a sustainable future, Part Learning science: Conceptual understanding/strand 1(co-ed. Finlayson O. \& Pinto R.), (pp. 271-277). Helsinki, Finland: University of Helsinki. ISBN 978-951-51-1541-6.

Ristić Dedić, Z., Jokić, B., Šabić, J. 2011. Analiza sadržaja i rezultata ispita državne mature iz biologije. NCVVO i IDIZ, Zagreb, $165 \mathrm{str}$.

SRCE 2018. Sustav za e-učenje Moodle u društvu - MoD (Moodle Community). Centar za e-učenje, Sveučilišni računski centar (Srce), Sveučilište u Zagrebu https://mod.srce.hr/

Swarup, S., Mahmud, M. M., Lakkaraju, K., Ray, S. R. 2005. Cumulative learning: Towards designing cognitive architectures for artificial agents that have a lifetime. IDEALS, http://hdl.handle.net/2142/10961

Tekkaya, C. 2002. Misconceptions as barrier to understanding biology. Hacettepe Üniversitesi Eğitim Fakültesi Dergisi, 23(23), 259-266.

Yew, E. H., Chng, E., Schmidt, H. G. 2011. Is learning in problem-based learning cumulative?. Advances in Health Sciences Education, 16(4), 449-464. https://doi.org/10.1007/s10459-010-9267-y 